О. К. КОЛОСКОВА, Т. М. БІЛОУС, Г. А. БІЛИК, М. В. ДІКАЛ, Ю. В. ЛОМАКІНА, Т. Г. КОПЧУК (Чернівці)

\title{
ШЛЯХИ ОПТИМІЗАЦЇ̈ ЛІКУВАННЯ БРОНХІАЛЬНОЇ АСТМИ У ДІТЕЙ З УРАХУВАННЯМ ФЕНОТИПОВОЇ, ЕНДОТИПОВОЇ ТА ГЕНОТИПОВОЇ НЕОДНОРІДНОСТІ ЗАХВОРЮВАННЯ
}

Кафедра педіатрії та дитячих інфекційних хвороб (зав. - проф. О. К. Колоскова) ВДНЗ України «Буковинський державний медичний університет» <koloskov.ek@gmail.com>

\begin{abstract}
Встановлено, що у дітей з делеційним поліморфізмом генів GSTT $_{1}$ i GSTM порівняно $_{1}$ пацієнтами без нього у конденсаті видихуваного повітря накопичуються продукти, які надлишково утворюються внаслідок підвищення активності процесів окислювального стресу та накопичення продуктів окислювальної модифікащї протеїнів на фоні дефіииту антиоксидантних прочесів захисту. Відзначено, що у хворих з генотипами $G S T T_{1}+M_{1}^{-}, G S T T_{1}-M_{1}+$ або $G S T T_{1}-M_{1}-$ базисну терапію доцільно посилювати за рахунок $\beta_{2}$-агоністів тривалої дії, метилксантинів пролонгованої дії чи селективних блокаторів гістамінових рещепторів.
\end{abstract}

Ключові слова: бронхіальна астма; діти; поліморфізм генів.

Вступ. Глобальне поширення бронхіальної астми (БА) у дітей викликає велику стурбованість лікарів та суспільства [3]. Серед ряду невирішених проблем з даної нозології залишається, можливо, найбільш актуальною відсутність консенсусу у визначенні астми [14] через відсутність так званого золотого стандарту iii діагностики. Дедалі більше дослідників вважають, що БА - узагальнюючий термін, який охоплює ряд різнорідних захворювань, що представляють з аналогічними симптомами, такі як повторювані епізоди свистячих хрипів, кашлю, задишки і утрудненого дихання [12]. БА належить до успадкованої патології, але закономірності успадкування складні і часом суперечливі. Так, генетичні дослідження показали незадовільну реплікацію астма-фенотипу і тому важко пояснити дуже незначну частку реалізації схильності до неї [11]. Швидке збільшення поширення БА наприкінці минулого століття переконливо вказує на роль екологічного впливу у формуванні астма-фенотипу. Але недосягнення мети протизапального лікування у значної кількості пацієнтів потребує подальших наукових досліджень.

Для досягнення прогресу в даній галузі знань та розробки адресних і ефективних методів лікування пацієнтів з астма-синдромом необхідне точне визначення захворювань, що знаходяться під «парасолькою» БА, з наступним встановленням їх генетичної та екологічної складової. Тоді як фенотип є показником певних характеристик або симптомів захворювання, ендотипи являють собою «підтип нозології, що визначається окремим функціональним чи патофізіологічним механізмом» [9]. Вважають, що різні ендотипи БА мають унікальні основні патофізіологічні механізми і в їх основі лежить ряд генетичних та екологічних предикторів. Клінічне значення цього полягає в тому, що різні ендотипи астми по-різному реагують на лікування, що у кінцевому результаті дозволить відійти від принципу «один розмір на усіх» до більш цілеспрямованої персоніфікованої або стратифікованої терапії [8]. Виокремлення різних фенотипів, узагальнених категорією «астма», є важливим кроком на шляху до оптимізації стратегії їі лікування з позицій ендотипової неоднорідності, зумовленої різними базовими патофізіологічними механізмами [9]. Так, на підставі лонгітудинального спостереження за 826 дітьми з візингом виокремлено такі візинг-фенотипи у дітей раннього віку: 1 - діти, у яких ніколи не було візингу (51 \%); 2 - транзиторний візинг дітей до трирічного віку з припиненням бронхообструктивних епізодів до досягнення 6 років (20\%); 3 - астма пізнього початку у віці 6 років (15\%); 4 - постійний візинг від початку життя до досягнення 6 років (4\%) [10]. Таким чином, у понад 
половини немовлят візинг-синдром є тимчасовим, пов'язаним із зменшенням функції дихальних шляхів у грудному віці, який не асоціюється з високим ризиком формування БА або алергії у більш старшому віці.

Отже, особливо актуальним є пошук, по можливості, неінвазивних біомаркерів, які б вже у ранньому періоді життя дозволили віддиференціювати ранній початок персистувального візингу від транзиторного фенотипу. У зв’язку з цим вивчали прогностичні властивості еозинофілії як потенційного біомаркера [7], зміни в імунній системі при IgE-опосередкованих фенотипах БА [5]. Останнім часом дослідження спрямовані на розробку достовірної діагностики БА вже у віці від 2 до 3 років з використанням неінвазивних біомаркерів, таких як леткі і нелеткі запальні маркери, зокрема цитокіни, хемокіни, у видихованому повітрі [6]. На думку ряду вчених, це перспективний шлях, оскільки у майбутньому неінвазивні біомаркери і, імовірно, отримають своє застосування у ранній діагностиці і профілактиці БА [4].

Видихувана фракція оксиду азоту (FeNO), за даними літератури, свідчить про тяжкість запалення дихальних шляхів за Th2-механізмом, є біомаркером окремих астма-ендотипів, тісно корелює з атопією, характеризується неінвазивністю [2, 13]. Так, уже у віці 1 міс збільшення кількості FeNO відмічено у новонароджених 3 рецидивами візинг-синдрому впродовж першого року життя [1].

Отже, основною тенденцією в астмології є уточнення фенотипів БА з визначенням їх генетичних і екологічних компонентів, оскільки саме підхід з позицій неоднорідності БА сприятиме розвитку персоналізованого лікування, включаючи стратегії менеджменту та профілактики захворювання в дитячому віці.

Мета дослідження - оптимізація базисного протизапального лікування БА 3 урахуванням особливостей місцевого запального процесу дихальних шляхів у хворих у разі наявності чи відсутності делеційного поліморфізму генів GSTT та GSTM .

Матеріали і методи. Для встановлення ефективності терапії БА залежно від активності II фази системи детоксикації ксенобіотиків у дітей шкільного віку методом генетично-молекулярного аналізу встановлено поліморфізм генів сімей-

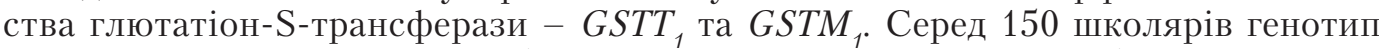
$G S T T_{1}+M_{1}+$ відмічено у 69 (46\%), генотип $G S T T_{1}-M_{1}+-$ у $19(12,7 \%), G S T T_{1}+M_{1}--$ у $48(32 \%)$ дітей, $G S T T_{1}-M_{1}-$ - у 14 (9,3 \%). Виходячи з отриманих результатів, усіх обстежених хворих розподілили на дві клінічні групи. Основну (I) клінічну групу становили 69 хворих на БА, у яких не відмічено делеційного поліморфізму генів, що вивчали, тому генотип визначали як $G S T T_{1}+M_{1}+$. Середній вік 10,71 року, хлопчиків було 48, дівчаток - 21. До групи порівняння (II) увійшов 81 хворий, у яких виявляли делеційний поліморфізм генів, що вивчали, ферментів детоксикації у гомо- та гетерозиготному варіантах, які проявлялися у генотипі $G S T T_{1}+M_{1}-, G S T T_{1}-M_{1}+$ та $G S T T_{1}-M_{1}-$. Хлопчиків було 65,43 \%, дівчаток 34,57 \%, середній вік хворих становив 10,75 року. За тривалістю, тяжкістю та іншими клінічними характеристиками групи порівняння статистично достовірно не різнилися.

Для характеристики вираженості місцевого запального процесу бронхів досліджували конденсат видихуваного повітря (КВП), який отримували у кількості 1,5-2 мл у період відсутності приступу за допомогою спроектованого нами конденсора. У конденсаті видихуваного повітря визначали такі біохімічні показники: вміст загального білка методом О. H. Lowry, альдегід- і кетопохідних 2,4-динітрофенілгідразонів основного та нейтрального характеру за методикою О. Є. Дубініної і співавт., активність каталази за М. А. Королюк та співавт., а також концентрацію метаболітів монооксиду азоту (FeNO, MMOH) за Н. Л. Ємченко та співавт. у модифікації А. І. Гоженка (2002).

Отримані результати дослідження аналізували методами біостатистики та клінічної епідеміології. При нормальному розподілі і великих вибірках використовували параметричні методи аналізу, а при малих вибірках - непараметричні. Діагностичну цінність тестів визначали з урахуванням чутливості (ЧТ), специфічності (СТ), позитивної (ПЦ+) та негативної (ПЦ-) передбачуваної цінності, позитивної $($ ПВ +$)$ і негативної (ПВ-) посттестової вірогідності. При проведенні 
популяційного аналізу оцінювали атрибутивний (АР) та відносний (BР) ризики, а також співвідношення шансів (СШ) з обчисленням довірчих інтервалів для відносного ризику і відношення шансів (95 \% ДІ). Статистичний аналіз здійснювали за програмою Statistica-v.6.0 на комп'ютері типу IBM.

Результати та їх обговорення. У дітей з генотипом $G S T T_{1}+M_{1}+$ вміст метаболітів монооксиду азоту (ММОА) у КВП у середньому становив $(43,53 \pm 5,54)$ мкмоль/л (95\% ДI: 19,66-67,41), а у дітей II групи - (48,87 $\pm 6,37)$ мкмоль/л (95 \% ДІ: 27,16-54,22) (Р > 0,05), що відповідало результатам обстеження хворих у період після усунення загострення БА. Так, у період відсутності приступу вміст ММОА у КВП становив відповідно $(40,56 \pm 4,02)$ мкмоль/л та $(42,08 \pm 3,82)$ мкмоль/л $(\mathrm{P}>0,05)$. Показано, що делеційний поліморфізм генів, що вивчали удвічі підвищував ризик більш вираженого місцевого запального процесу в бронхах (вміст ММОА > 45 мкмоль/л): СШ - 2 (95\% ДІ: 0,5-8,5), ВР - 1,3 (95\% ДI: 0,5-3,6), АР - 17 \%. Використання даного біохімічного показника підвищувало посттестову вірогідність (ПВ +) делеційного поліморфізму генів, що вивчали, на 11,54 \% при позитивному результаті, а при негативному (ПВ-) зменшувало до $44,44 \%$.

Нами не встановлено суттєвих розбіжностей у середніх значеннях інших біохімічних показників КВП. Так, вміст загального білка становив $(3,45 \pm 1,55)$ г/л у I групі та $(3,68 \pm 0,90)$ г/л у дітей II групи $(\mathrm{P}>0,05)$. У період стійкої клінічної ремісії у дітей без поліморфізму генів $G S T T_{1}$ та $G S T M_{1}$ порівняно з періодом після загострення БА зменшився вміст у КВП білка нейтрального характеру до $(4,01 \pm 0,23)$ ммоль/г Е 370 білка, а основного характеру - до $(27,20 \pm 3,76)$ ммоль/г Е 430 білка ( $\mathrm{P}>0,05)$, що, напевно, свідчило про зниження запального процесу в дихальних шляхах. У дітей групи порівняння дані показники відповідно становили $(6,82 \pm 3,45)$ ммоль/г Е 370 білка та $(60,13 \pm 36,59)$ ммоль/г Е 430 білка (порівняно з періодом загострення $\mathrm{P}>0,05$ ) та мали тенденцію до презентації більш вираженого локального запального процесу порівняно з хворими без делеційного поліморфізму генів $G S T T_{1}$ i $G S T M_{1}$.

У період відсутності приступу у пацієнтів I групи активність каталази в КВП становила в середньому $(42,45 \pm 9,56)$ мкмоль/(хв - мг білка), а у хворих II групи - $(53,85 \pm 14,82)$ мкмоль $/($ хв - мг білка) $(\mathrm{P}>0,05)$. Проте у міжприступному періоді у хворих з генотипом $G S T T_{1}+M_{1}-, G S T T_{1}-M_{1}+$ або $G S T T_{1}-M_{1}$ - визначали достовірно нижчі показники активності каталази у КВП. Так, у пацієнтів I групи активність каталази в КВП у період клінічної ремісії становила в середньому $(25,54 \pm 5,16)$ мкмоль/(хв - мг білка), а у хворих з делеційним поліморфізмом зазначених генів детоксикації ксенобіотиків - лише $(9,70 \pm 4,21)$ мкмоль / (хв · мг білка) $(\mathrm{P}<0,05)$. Отже, рівень активності основного ключового ферменту антиоксидантної системи, що не перевищував 50 мкмоль/(хв · мг білка), в 2,4 раза підвищував шанси делеційного поліморфізму генів детоксикації: СШ - 2,4 (95 \% ДІ: 0,58-9,93), ВР - 1,54 (95 \% ДІ: 1,12-2,1), АР - 22 \%. Чутливість даного біомаркера у виявленні делеційного поліморфізму генів II фази системи детоксикації становила 85,7 \% (95 \% ДІ: 67,33-95,97 \%), специфічність - 28,57 \% (95 \% ДІ: 11,28-52,18), передбачувана цінність позитивного результату - 61,54 \% (95 \% ДІ: 44,62-76,64 \%), передбачувана цінність негативного результату - 60 \% (95 \% ДІ: 26,24-87,84 \%), посттестова вірогідність (+) - 54,55 \%, посттестова вірогідність (-) - 33,33\%.

Таким чином, у дітей з делеційним поліморфізмом генів GSTT, та GSTM, порівняно з пацієнтами без нього у КВП накопичуються продукти запального процесу, які утворюються в надлишку через підвищення активності процесів окисного стресу та накопичення продуктів окислювальної модифікації білків на фоні виснаження процесів антиоксидантного захисту і зниженої активності каталази. Останнє, на нашу думку, відображає порушення процесів детоксикації алергенів в організмі цих хворих.

Аналіз результатів базисного лікування дітей груп порівняння показав, що у кожної другої дитини із збереженою функціональною активністю генів, що ви- 
вчали, та лише у третини пацієнтів з делеційним поліморфізмом базисна терапія відповідала Кроку 3. Разом з тим в 1,5 раза частіше у дітей II групи використовували низькі дози інгаляційних кортикостероїдів (ІГКС) або антагоністи лейкотрієнових рецепторів у вигляді монотерапії. Оскільки тяжкість захворювання в обстежених клінічних груп порівняння практично збігалася вони достовірно не різнилися за основними клінічними показниками. Отримані дані свідчили про необхідність активнішої протизапальної терапії у міжприступному періоді у хворих з делеційним поліморфізмом генів $G S T T_{1}$ та $G S T M_{1}$, який, мабуть, спричинив глибші зміни у бронхіальному дереві.

Виходячи з результатів проведеної оцінки контролю за перебігом захворювання у клінічних групах, сформованих за показниками молекулярно-генетичного аналізу генів $G S T T_{1}$ та $G S T M_{1}$, вважаємо за необхідне розробку індивідуалізованої лікувальної тактики згідно з рекомендаціями вітчизняних і міжнародних регламентуючих документів з лікування і профілактики БА. Підгрунтям для цього є виявлені інфламатометричні особливості та відмінності у результативності терапії хворих залежно від генотипових характеристик, що вивчали.

Висновки. Узагальнюючи наведені вище дані, можемо дійти висновку, що наявність чи відсутність делеційного поліморфізму генів $G S T T_{1}$ та $G S T M_{1}$ супроводжується формуванням окремих фенотипових відмінностей у перебігу запального процесу в дихальних шляхах, а це зумовлює диференційований підхід до лікування. Так, за відсутності делеційного поліморфізму алергічне запалення дихальних шляхів у хворих з генотипом $G S T T_{1}+M_{1}+$ слід контролювати посиленням протизапального ефекту стандартної терапії завдяки комбінації базисних інгаляційних кортикостероїдів з $\beta_{2}$-агоністами тривалої дії, антилейкотрієновими засобами, препаратами імуномоделюючого спрямування. У разі делеційного поліморфізму вказаних генів алергічне запалення дихальних шляхів характеризується тенденцією до тяжчого перебігу з порушенням у системі антиоксидантного захисту, можливо, через особливості функціонування системи детоксикації ксенобіотиків. Тому у хворих з генотипом $G S T T_{1}+M_{1}-, G S T T_{1}-M_{1}+$ або $G S T T_{1}-M_{1}$ - базисну терапію доцільно посилювати за рахунок $\beta_{2}$-агоністів тривалої дії, метилксантинів пролонгованої дії, кромонів або селективних блокаторів гістамінових рецепторів.

$$
\text { Спи сок л і те ратур и }
$$

1. Baraldi E., De Jongste J. C. Measurement of exhaled nitric oxide in children // Eur. Respir. J. 2002. - Vol. 20, N 1. - P. 223-237.

2. Bates C. A., Silkoff P. E. Exhaled nitric oxide in asthma: from bench to bedside // J. Allergy Clin. Immunol. - 2003. - Vol. 111, N 2. - P. 256-262.

3. Bousquet J., Clark T.J., Hurd S. et al. GINA guidelines on asthma and beyond // Allergy. - 2007. Vol. 62, N 2. - P. 102-112.

4. Hauk P.J., Krawiec M., Murphy J. et al. Neutrophilic airway inflammation and association with bacterial lipopolysaccharide in children with asthma and wheezing // Pediatr. Pulmonol. 2008. - Vol. 43, N 9. - P. 916-923.

5. Heaton T., Rowe J., Turner S. et al. An immunoepidemiological approach to asthma: identification of in-vitro T-cell response patterns associated with different wheezing phenotypes in children // Lancet. - 2005. - Vol. 365. - P. 142-149.

6. Kant Van De K. D., Klaassen E. M., Jobsis Q. et al. Early diagnosis of asthma in young children by using non-invasive biomarkers of airway inflammation and early lung function measurements: study protocol of a case-control study // BMC Public. Health. - 2009. - Vol. 9. - P. 1471-2458.

7. Klion A. D., Law M. A., Riemenschneider W. et al. Familial eosinophilia: a benign disorder? // Blood. - 2004. - Vol. 103, N 11. - P. 4050-4055.

8. Kurukulaaratchy R.J., Waterhouse L., Matthews S. M. et al. Are influences during pregnancy associated with wheezing phenotypes during the first decade of life? // Acta Paediatr. - 2005. Vol. 94, N 5. - P. 553-558.

9. LotvallJ., Akdis C. A., Bacharier L. B. et al. Asthma endotypes: a new approach to classification of disease entities within the asthma syndrome // J. Allergy Clin. Immunol. - 2011. - Vol. 127, N 2. - P. 355-360.

10. Martinez F.D., Wright A. L., Taussig L. M. et al. Asthma and wheezing in the first six years of life. The Group Health Medical Associates // N. Engl. J. Med. - 1995. - Vol. 332, N 3 ). - P. 133-138. 
11. Murk W., Walsh K., Hsu L. I. et al. Attempted replication of 50 reported asthma risk genes identifies a SNP in RAD50 as associated with childhood atopic asthma // Hum. Hered. - 2011. Vol. 71, N 2. - P. 97-105.

12. Papadopoulos N. G., Arakawa H., Carlsen K. H. et al. International consensus on (ICON) pediatric asthma // Allergy. - 2012. - Vol. 67, N 8. - P. 976- 997.

13. Valk Van Der R.J., Caudri D., Savenije O. et al. Childhood wheezing phenotypes and FeNO in atopic children at age 8 // Clin. Exp. Allergy. - 2012. - Vol. 42, N 9. - P. 1329-1336.

14. Wonderen Van K. E., Van Der Mark L. B., Mohrs J. et al. Different definitions in childhood asthma: how dependable is the dependent variable? // Eur. Respir. J. - 2010. - Vol. 36, N 1. - P. 48-56.

\author{
ПУТИ ОПТИМИЗАЦИИ ЛЕЧЕНИЯ БРОНХИАЛЬНОЙ АСТМЫ \\ У ДЕТЕЙ С УЧЁТОМ ФЕНОТИПИЧЕСКОЙ, ЭНДОТИПИЧЕСКОЙ \\ И ГЕНОТИПИЧЕСКОЙ НЕОДНОРОДНОСТИ ЗАБОЛЕВАНИЯ
}

Е. К. Колоскова, Т. М. Белоус, Г. А. Бильк, М. В. Дикал, Ю. В. Ломакина, Т. Г. Копчук (Черновцы)

Установлено, что у детей с делеционным полиморфизмом генов GSTT 1 и GSTM 1 по сравнению с пациентами без него в конденсате выдыхаемого воздуха накапливаются продукты воспалительного процесса, которые образуются в избытке из-за повышения активности процессов окислительного стресса и накопления продуктов окислительной модификации белков на фоне истощения процессов антиоксидантной защиты. Отмечено, что у больных с генотипами $G S T T_{1}+M_{1}-, G S T T_{1}-M_{1}+$ или $G S T T_{1}-M_{1}$-базисную терапию целесообразно усиливать за счёт $\beta_{2}$-агонистов длительного действия, метилксантинов пролонгированного действия или селективных блокаторов гистаминовых рецепторов.

Ключевые слова: бронхиальная астма; дети; генетический полиморфизм.

\title{
WAYS TO OPTIMIZE THE TREATMENT OF BRONCHIAL ASTHMA IN CHILDREN TAKING INTO ACCOUNT OF PHENOTYPIC, ENDOTYPIC AND GENOTYPICAL GETEROGENEITY OF THE DISEASE
}

O. K. Koloskova, T. M. Bilous, G. A. Bilyk, M. V. Dikal,

Yu. V. Lomakina, T. G. Kopchuk (Chernivtsi, Ukraine)

Higher State Educational Establishment of Ukraine "Bukovinian State Medical University"

It has been established that the products of the inflammatory process accumulate in the condensate of exhaled air in children with deletion polymorphism of the genes GSTT and GSTM 1 compared with patients without it. These products are formed in excess due to the increased activity of oxidative stress processes and the accumulation of products of oxidative modification of proteins against the background of depletion of antioxidant protection processes. It was noted that in patients with the genotypes $G S T T_{1}+M_{1}-, G S T T_{1}-M_{1}+$ or $G S T T_{1}-M_{1}-$, it is advisable to increase the background therapy based on long-acting $\beta_{2}$-agonists, methylxanthines of prolonged action or selective histamine antagonists.

Key words: bronchial asthma; children; genetic polymorphism.

\author{
П. В. ФЕДОРИЧ (Київ)
}

\section{ДІАГНОСТИКА ТА ЛІКУВАННЯ ПОЄДНАНИХ УРАЖЕНЬ СЕЧОСТА- ТЕВОЇ СИСТЕМИ ТРИХОМОНАДАМИ РІЗНИХ ВИДІВ І МІКРООР- ГАНІЗМАМИ, АСОЩІЙОВАНИМИ З БАКТЕРІАЛЬНИМ ВАГІНОЗОМ}

Українська військово-медична академія <pvf9@meta.ua>

Дослідження поєднаних уражень сечостатевої системи, викликаних різними видами трихомонад та мікроорганізмами, асочійованими з БВ, є перспективним напрямом, вивчення якого здатне призвести до значного підвищення рівня діагностичного обстеження хворих на інфекщї, що передаються переважно статевим шляхом, та покращен- 